\title{
BLEACHED KRAFT PULP PRODUCTION FROM Pinus tecunumanii (Eguiluz e Perry) ${ }^{1}$
}

\author{
Leonel F. Torres², Roberto Melo ${ }^{2}$ and Jorge Luiz Colodette ${ }^{1}$
}

\begin{abstract}
The use of 12-year-old Pinus tecunumanii (Eguiluz e Perry) grown in Colombia was evaluated for bleached kraft pulp production. Kraft pulps of kappa number $30 \pm 1$ were produced, and oxygen delignified and bleached to $90 \%$ ISO with ECF processes. The bleached pulps produced under optimum conditions were evaluated with regard to their strength properties. Pinus tecunumanii wood required low effective alkali charge to reach the desired kappa number and the unbleached pulp showed high oxygen delignification efficiency and bleachability when a OD(EO)DED sequence was used. The bleached pulps presented good physical-mechanical properties, which are comparable to those obtained with more traditional pines such as Pinus taeda and Pinus radiata. The results demonstrate that this tropical pine species is a suitable raw material for bleached kraft pulp production.
\end{abstract}

Key words: Pinus tecunumanii, kraft pulp, ECF bleaching, strength properties.

\section{PRODUÇÃO DE POLPA KRAFT BRANQUEADA DE Pinus tecunumanii (Eguiluz e Perry)}

\begin{abstract}
RESUMO - Foram avaliadas amostras de Pinus tecunumanii de (Eguiluze Perry) com 12 anos de idade procedente da Colômbia, para produção de polpa de kraft branqueada. Produziram-se polpas kraft com número kappa $30 \pm 1$, deslignificada com oxigênio e branqueada a $90 \%$ ISO por processo ECF. As polpas branqueadas foram produzidas em condições ótimas e avaliadas com relação às suas propriedades de resistência. A madeira de Pinus tecunumanii exigiu baixa carga de álcali efetivo para alcançar o número kappa desejado, e a polpa marrom mostrou eficiência na deslignificação com oxigênio e alta branqueabilidade quando submetida à seqüência $O D(E O) D E D$. As polpas branqueadas apresentaram boas propriedades físico-mecânicas, em comparação com aquelas obtidas das espécies tradicionais de Pinus, como o Pinus taeda e o Pinus radiata. Os resultados indicaram que essa espécie de pinus tropical é uma matéria-prima satisfatória para produção de polpa de kraft branqueada.
\end{abstract}

Palavras-chave: Pinus tecunumanii, polpa de kraft, ECF branqueado e propriedades de força.

\section{INTRODUCTION}

The Colombian pulp and paper industry is faced with a chronic shortage of wood despite the high growth rate of wood species in this tropical country. Only 45,000 hectares of a total of 2.7 million hectares of potentially reforestable land in Colombia are used for planted forests. Other Latin American countries have much larger areas covered by forest plantations. For example, Brazil has 5 million hectares of planted forests, Chile, 2 million hectares, Argentina, 770,000 hectares and Venezuela, approximately 530,000 hectares (RESTREPO, 2003).

The planted forest wood supply shortage in Colombia has led to a shortage of pulp prodution and a permanent dependence on pulp imports, with 96,600 tons imported

${ }^{1}$ Recebido em $1^{\circ} .09 .2003$ e aceito para publicação em 25.11.2004.

${ }^{2}$ Pulp and Paper Laboratory of Universidade Federal de Viçosa, 36.570.000 Viçosa-MG, Brazil. E-mail:<colodette@ufv.br>.

${ }^{3}$ Forest Products Laboratory of Universidad de Concepción, Concepción, Chile. E-mail: <ltorresb@udec.cl>; <rmelo@udec.cl>. 
in 1999 and 105,300 tons in 2000. Additionally, all newsprint consumed in Colombia is imported and half the pulp used by the Colombian paper industry comes from recycled fibers (RESTREPO, 2003). The industry depends on two wood species for virgin fiber supply: Pinus patula and Eucalyptus globulus, as well as sugar cane bagasse. Sustained growth of the Colombian pulp and paper industry depends on development of new raw materials for kraft pulp production. Pinus tecunumanii (Eguiluz e Perry), identified officially by Eguiluz-Piedra and Perry in the early 1980's, is a potential new wood raw material for pulping (DVORAK et al., 2000). Preliminary evaluation suggested this species could be used to produce kraft pulp under conditions normally used for softwood kraft pulp production (WRIGHT et al., 1995; WRIGHT et al., 1996). However the detailed characterization of this pine species necessary to guide further tree-improvement programs is still lacking. The objective of this study was therefore to determine the fiber characteristics and the true potential of this species for producing high quality bleached kraft pulp.

\section{EXPERIMENTAL}

Twelve-year-old Pinus tecunumanii trees planted at a density of 1060 trees per hectare were used in this study. The plantation is located in Yolombó County, northeastern Antioquia, Colombia (altitude 1440 m; average annual temperature $21^{\circ} \mathrm{C}$; average annual precipitation $2200 \mathrm{~mm}$ ). Sample trees came from a 25meter-diameter circular plot. Average diameter at breast height (DBH) of the trees in the plot was $21.24 \mathrm{~cm}$ and average height was $21.44 \mathrm{~m}$. Three logs ( $1 \mathrm{~m}$ long) were cut at base height, half the commercial height and top of the commercial height ( $10 \mathrm{~cm}$ diameter $)$ from each of five trees within the parcel that were of average DBH. The logs were chipped, classified and dried to approximately $80 \%$ dryness. Chip density was determined using the TAPPI method 258 om-94. Fiber length, fiber diameter, cell-wall, thickness and lumen diameter were measured using an optical microscope.

Chips were pulped in a $4.7 \mathrm{~L}$ capacity $\mathrm{M} / \mathrm{K}$ laboratory digester. The pulping conditions used were: $30 \%$ sulfidity, a 4:1liquor to wood ratio, time of 90 minutes and maximum temperature of $170^{\circ} \mathrm{C}$. The effective alkali charge varied from $13 \%$ to $18 \% \mathrm{Na}_{2} \mathrm{O}$ and time to maximum temperature varied from 40 to $70 \mathrm{~min}$, to obtain pulp of kappa number
$30 \pm 1$. The cooked chips were disintegrated by vigorous agitation and the resulting pulp screened in a Valley flat screen. Pulp kappa number was determined according to TAPPI method T 236 om-85. Pulp metal contents were measured by atomic absorption spectroscopy after wet ashing the pulp according to TAPPI standards. Hexenuronic acids (HexAs) content was measured by high-pressure liquid chromatography using an ultraviolet (254 nm) detector, after complete acid hydrolysis of the pulp.

Table 1 presents the general oxygen delignification conditions used. Single $(\mathrm{O})$ and double (OO) stage oxygen delignification were carried out with 300 g ovendry (o.d.) samples in a Quantum Mark V mixer/reactor (Twinsburg, USA) with five repetitions. ECF bleaching by the sequences DEoDED and DEopDED was carried out using the conditions listed in Table 2. The bleaching sequences were compared based on total chemical consumption, total yield and pulp quality. The first chlorine dioxide stage $\left(\mathrm{D}_{0}\right)$ was carried out with 300 g o.d. samples in polyethylene bags and the alkaline/ peroxide extractions (Eo / Eop) with 250 g o.d. pulp samples in the Quantum Reactor equipped with Teflonlined mixing vessel. The final $\mathrm{D}$ stages $\left(\mathrm{D}_{1}\right.$ and $\left.\mathrm{D}_{2}\right)$ were also conducted in polyethylene bags with 150 g o.d. pulp samples. All bleaching stages were run in duplicate and the samples were washed with excess distilled water after each stage. Brightness reversion was measured on hand sheets heated for four hours at $105 \pm 3{ }^{\circ} \mathrm{C}$ and $0 \%$ relative humidity.

Pulp optical and physical-mechanical properties were analyzed according to TAPPI standard procedures. Strength properties were determined on samples refined in a PFI mill (0, 4000, 6000 and 8000 revolutions).

Table 1 - Single (O) and double (OO) stage oxygen delignification conditions

Quadro 1 - Condições para estágio simples $(O)$ e duplo estágio (OO) de deslignificação com oxigênio

\begin{tabular}{lcc}
\hline Conditions & $\mathrm{O}$ & $(\mathrm{OO})$ \\
\hline Consistency, $\%$ & 10 & 10 \\
Time, min & 35 & $15+45$ \\
Temperature, ${ }^{\circ} \mathrm{C}$ & 90 & $90+95$ \\
Pressure, kPa & 600 & 600 \\
$\mathrm{NaOH}, \mathrm{kg} / \mathrm{o} . \mathrm{d}$. metric ton & 34.8 & $34.8+19.5$ \\
$\mathrm{MgSO}_{4} \cdot{ }^{7 \mathrm{H}_{2}}$ 0, kg/o.d. metric ton & 1 & 5 \\
\hline
\end{tabular}


Table 2 - General bleaching conditions

Quadro 2 - Condições gerais de branqueamento

\begin{tabular}{|c|c|c|c|c|c|c|}
\hline \multirow[t]{2}{*}{ Conditions } & \multicolumn{6}{|c|}{ Bleaching Stage } \\
\hline & $\mathrm{D}_{0}$ & Eo & Eop & $\mathrm{D}_{1}$ & $\mathrm{E}$ & $\mathrm{D}_{2}$ \\
\hline Consistency, \% & 11 & 11 & 11 & 11 & 11 & 11 \\
\hline Time, $\min$ & 45 & $20+45$ & $20+45$ & 150 & 15 & 180 \\
\hline Temperature, ${ }^{\circ} \mathrm{C}$ & 65 & 85 & 85 & 70 & 70 & 70 \\
\hline Kappa Factor & 0.24 & - & - & - & - & - \\
\hline $\mathrm{NaOH}, \mathrm{kg} / \mathrm{o} . \mathrm{d}$. metric ton & 1 & 11.5 & 11.5 & - & 2 & - \\
\hline $\mathrm{O}_{2}, \mathrm{~kg} / \mathrm{o} . \mathrm{d}$. metric ton & - & 3 & 3 & - & - & - \\
\hline $\mathrm{H}_{2} \mathrm{O}_{2}, \mathrm{~kg} / \mathrm{o}$.d. metric ton & - & & 2 & - & - & - \\
\hline Pressure, $\mathrm{kPa}$ & - & 200 & 200 & - & - & - \\
\hline
\end{tabular}

\section{RESULTS AND DISCUSSION}

\section{Fiber characteristics}

The 12 year-old Pinus tecunumanii wood had a relatively high density $\left(466 \mathrm{~kg} / \mathrm{m}^{3}\right)$ compared to the values cited in previous studies of the same species and to densities of other Pinus species used for pulp production (Table 3 ). A Brazilian study reported a density of $445 \mathrm{~kg} / \mathrm{m}^{3}$ for 12-year-old Pinus tecunumanii (SILVA et al., 1994) while the density of 8 year-old Pinus tecunumanii was found to be $361 \mathrm{~kg} / \mathrm{m}^{3}$ in a Colombian study (GOMES et al., 1992). Table 3 presents the results of Pinus tecunumanii fiber analysis. This species' fibers are longer $(3.96 \mathrm{~mm})$ than those of other pine species used to produce kraft pulp. For example, fibers of 12-year-old Pinus taeda from a commercial plantation in southern Brazil are $3.53 \mathrm{~mm}$ long (GOMES et al., 1992). Cell-wall thickness and lumen diameter are directly correlated to high density. These properties translate into fibers with elevated resistance against collapse since the more rigid fibers maintain their original form (tubular). The result is a reduction in interfiber bonding and hence lowers tensile and burst strengths and increases tear strength.

Table 3 - Wood density and fibre morphology 12-year-old Pinus tecunumanii

Quadro 3 - Densidade da madeira e morfologia das fibras de Pinus tecunumanii aos 12 anos de idade

\begin{tabular}{lc}
\hline Parameters & Values \\
\hline Wood density, $\mathrm{kg} / \mathrm{m}^{3}$ & 466 \\
Fibre length, $\mathrm{mm}$ & 3.96 \\
Fiber diameter, $\mu \mathrm{m}$ & 51.93 \\
Lumen diameter, $\mu \mathrm{m}$ & 32.96 \\
Fiber wall thickness, $\mu \mathrm{m}$ & 9.48 \\
\hline
\end{tabular}

\section{Pulping}

Pulp of kappa number $30 \pm 1$ was produced using $16 \%$ effective alkali (expressed as equivalent $\mathrm{Na}_{2} \mathrm{O}$ ) and a time to maximum temperature of $40 \mathrm{~min}$. This amount of alkali is less than that required by Pinus patula $(18.5 \%)$ and Pinus maximinoii (19.1\%) to produce pulp of the same kappa number (WRIGHT et al., 1995). Screened pulp yield was $43.7 \%$, which can be considered reasonable for the Pinus genus, and is superior to that obtained from Pinus patula (41.1\%), Pinus elliotii (42.5\%) and Pinus taeda (40.5\%) pulped to a kappa number 30+1 (RODRÍGUEZ e TORRES, 1995).

Table 4 presents other unbleached pulp characteristics of the 12-year-old Pinus tecunumanii. The HexAs content in the unbleached pulp is similar to that of other softwood kraft pulps. Softwood pulps contain lower amounts of xylans and therefore lower HexAs contents than hardwood pulps. Pulp iron (76.90 $\mathrm{mg} / \mathrm{kg})$ and copper $(23.76 \mathrm{mg} / \mathrm{kg})$ contents are greater than those found in pulps from other softwood species. Kraft pulp produced from mixtures of Pinus elliotii and Pinus taeda contained $23 \mathrm{mg} \mathrm{Fe} / \mathrm{kg}$ and $3.3 \mathrm{mg}$ $\mathrm{Cu} / \mathrm{kg}$ (SALOMÃO, 2001). The higher values found in the present study may probably have come from the water supply, pulp digester corrosion or a greater soil metals content in the plantation where the samples were collected, which is located in a mining zone.

\section{Oxygen delignification}

Oxygen delignification results are presented in Table 5. Delignification was higher in the double (62\%) than in the single $(41.7 \%)$ oxygen stage. These values are within the ranges considered suitable by several authors (POUKKA el al., 1999; SOINIL et al., 1998) for application of a double oxygen stage process for 
pine kraft pulp. Single and double stage oxygen delignification exhibited the same selectivity, a property related to the rates of lignin removal and carbohydrate degradation (DENCE e REEVE, 1996). Transition metals play an important role in oxygen delignification since radicals generated in the presence of these metals participate in reactions that degrade both lignin and cellulose. Cellulose depolimerization reactions result in pulp strength loss (SOINIL el al., 1998; BROWN e DAWE, 1996). A greater viscosity loss was observed in the double stage oxygen delignification. Viscosity loss was caused by carbohydrate depolimerization resulting from hydrolysis of â-glycoside bonds. The double stage oxygen delignification produced higher brightness pulp (35.4\%ISO) than the single stage process (29.8\% ISO).

Table 4 - Characteristics of kraft pulp produced from 12year-old Pinus tecunumanii

Quadro 4-Características da polpa kraft produzida com madeira de Pinus tecunumanii aos 12 anos de idade

\begin{tabular}{lcc}
\hline Parameter & Values \\
\hline Screened Yield, \% & 43.7 \\
Effective Alkali, \% NaOH & & 16.0 \\
Kappa number & & 30 \\
Viscosity, mPa.s & & 34.0 \\
Brightness, \%ISO & 34.2 \\
Hexenuronic acid, mmol/kg & & 33.0 \\
Metals, mg/kg & & 76 \\
& $\mathrm{Fe}$ & 23 \\
& $\mathrm{Cu}$ & 7 \\
& $\mathrm{Mn}$ & 1036 \\
& $\mathrm{Ca}$ & 210 \\
\hline
\end{tabular}

Table 5 - Oxygen delignification results (see Table 4 for initial pulp characteristics)

Quadro 5 - Resultados da deslignificação com oxigênio (ver Quadro 4, com a caracterização inicial da polpa)

\begin{tabular}{lcc}
\hline Results & \multicolumn{2}{c}{ O-Stage } \\
\cline { 2 - 3 } & $\mathrm{O}$ & OO \\
\hline Kappa number & 17.5 & 11.4 \\
Viscosity, mPa.s & 21.1 & 14.7 \\
$\Delta$ Kappa, \% & 41.7 & 62.0 \\
$\Delta$ Viscosity, \% & 37.9 & 56.8 \\
Selectivity* & 1.10 & 1.09 \\
Brightness, \%ISO & 29.8 & 35.4 \\
Yield, \% & 97.1 & 96.2 \\
\hline
\end{tabular}

$*$ selectivity $=\Delta \mathrm{Kappa}(\%) / \Delta \mathrm{Viscosity}(\%)$.

\section{Bleaching}

It can be seen from the bleaching results shown in Table 6 that the O/ODEopDED sequence required less chlorine dioxide charge than other sequence to produce $90 \%$ ISO brightness pulp. Pulp bleached in these sequences presented the lowest viscosity, although the viscosity (11.0 mPa.s) was still within the limits required by the pulp industry. For pulps produced by the same oxygen delignification process (single versus double stage), the use of hydrogen peroxide in the extraction stage resulted in lower final viscosity. This may have been caused by the presence of transition metals, such as $\mathrm{Cu}, \mathrm{Fe}$ and $\mathrm{Mn}$, that cause peroxide decomposition and formation of hydroxyl (HO) and superoxide $\left(\mathrm{O}_{2}^{--}\right)$radicals. Intermediate peroxide decomposition species, including these radicals, do not bleach the pulp but can cause cellulose degradation (JOHNSON, 1994; HOBBS e ABBOT, 1992).

Table 6 - Results of bleaching Pinus tecunumanii kraft-O pulps to 90\% ISO by the ECF sequences ODEoDED, ODEopDED, OODEODED and OODEopDED

Quadro 6 - Resultados dos branqueamentos da polpa kraft-O 90\% ISO de Pinus tecunumaniipelas seqüências ODEoDED, ODEOPDED, OODEODED e OODEOPDED

\begin{tabular}{|c|c|c|c|c|}
\hline \multirow[t]{2}{*}{ Parameters } & \multicolumn{4}{|c|}{ Sequence } \\
\hline & ODEoDED & ODEopDED & O/ODEoDED & O/ODEopDED \\
\hline Brightness, \%ISO & 90.0 & 90.1 & 90.3 & 90.0 \\
\hline Reversion, \% ISO & 3.1 & 3.1 & 2.6 & 2.3 \\
\hline Viscosity, mPa.s & 15.3 & 13.8 & 12.2 & 11 \\
\hline $\mathrm{ClO}_{2}$ as $\mathrm{Cl}_{2}$, kg/o.d.t. & 102 & 87 & 70 & 57 \\
\hline $\mathrm{H}_{2} \mathrm{O}_{2}, \mathrm{~kg} / \mathrm{o}$. d.t. & - & 2 & - & 2 \\
\hline Bleaching Yield, \% & 98.2 & 98.0 & 97.8 & 97.0 \\
\hline Total Yield*, \% & 95.3 & 95.1 & 94.1 & 93.3 \\
\hline
\end{tabular}

$* \mathrm{O}_{2}($ Table $\mathrm{V})+$ Bleaching.

R. Árvore, Viçosa-MG, v.29, n.3, p.489-494, 2005 


\section{Pulp quality}

Figures 1, 2, 3 and 4 present the tensile index, tear index, burst index and tensile energy absorption (TEA) as a function of drainability ( $\left.{ }^{\circ} \mathrm{SR}\right)$ for the pulps bleached in the four sequences. Maximum tear index values were reached quickly at low refining levels, implying that little refining is needed to reach high tear strength values. The pulp produced using a single oxygen delignification stage presented higher tensile index, burst index and TEA and was also easier to refine, possibly because this pulp suffered less fiber cell wall damage and less removal of hemiceluloses. Pulps bleached using a peroxide reinforced extraction stage tended to present lower drainability. Peroxide may cause softening of fiber cell walls, resulting in greater compaction during hand sheet formation, which is strongly correlated with the interfiber bond-forming capacity. Tensile strength is controlled by several factors, such as individual fiber strength, fiber length and hand sheet formation and structure. Individual fiber strength is a result of other properties, including the fibrilar angle, cellulose content and fiber structure defects.

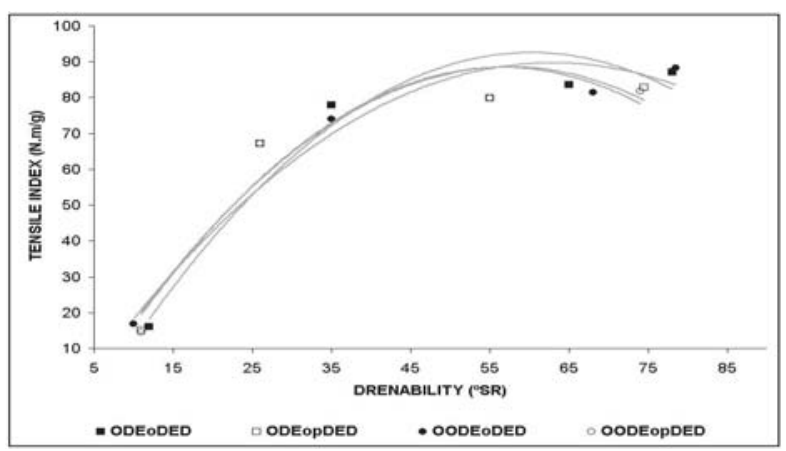

Figure 1 - Tensile strength as a function of drainability. Figura 1 - Resistência à tração em função da drenabilidade.

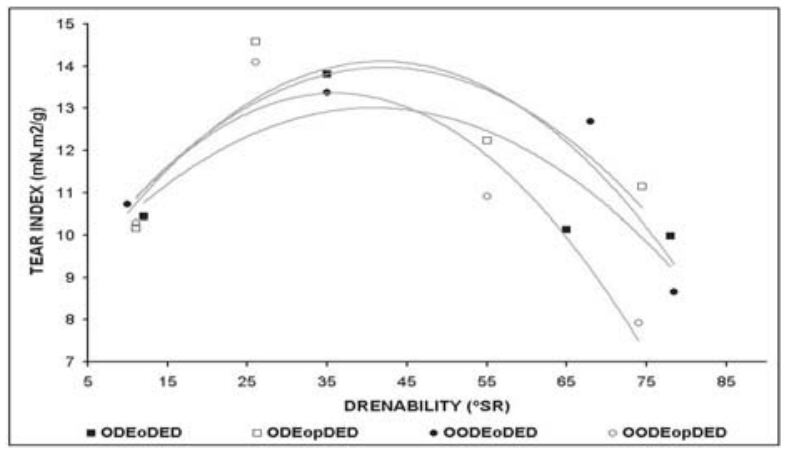

Figure 2 - Tear strength as a function of drainability. Figura 2 - Resistência ao rasgo em função da drenabilidade.

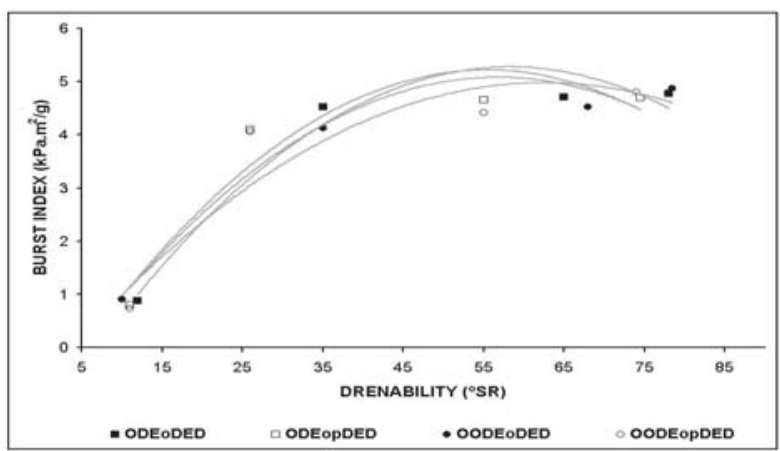

Figure 3 - Burst strength as a function of drainability. Figura 3 - Resistência ao estouro em função da drenabilidade.

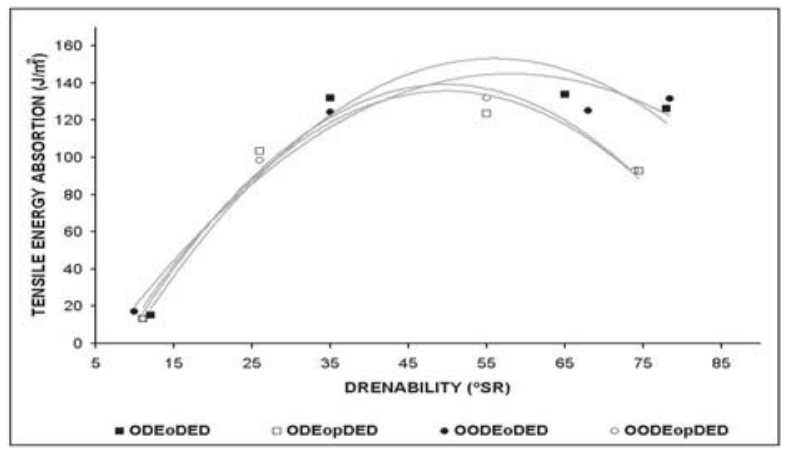

Figure 4-Tensile energy absorption as a function of drainability. Figura 4-Energia de tensão absorvida (TEA) em função da drenabilidade.

\section{CONCLUSIONS}

The results obtained in this study demonstrate that Pinus tecunumanii (Eguiluz e Perry) wood presents morphological and technological characteristics suitable for production of bleached kraft pulp, making this species an excellent raw material source for the Colombian pulp and paper industry.

\section{REFERENCES}

BROWN, G.; DAWE, R. Effects of metal ions on oxygen delignification of kraft pulp.In: INTERNATIONAL PULPBLEACHING CONFERENCE, 1996, Washington.

Proceddings... Washington: Tappi Press, 1996. p. 383-390.

DENCE, C.W.; REEVE, D.W. Pulp Bleaching. Principles and practice. Atlanta: TAPPI PRESS, 1996. p. 215-237.

R. Árvore, Viçosa-MG, v.29, n.3, p.489-494, 2005 
DVORAK, W.S. et al. Pinus tecunumanii. In: Conservation \& Testing of Tropical \& Subtropical Forest Tree Species. Raleigh: CAMCORE Cooperative, College of Natural Resources, NCSU. 2000. p. 188-209.

HARTLER, N. Present and future of kraft pulping. Nordic Pulp and Paper Research Journal, v.12, n.2, p. 115-118, 1997.

HOBBS, G.; ABBOT, J. The role of radical species in peroxide bleaching processes. Appita Journal, v.45, n.5, p. 344-348, 1992.

JOHNSON, S. Optimal use of hydrogen peroxide. Tappi Journal., v.77, n.7, p-262-264, 1994.

LACHENAL, D.; DE CHOUDENS, C.; MONZIE P. Hydrogen peroxide as a delignifying agent.

Tappi Journal, v.63, n.4, p. 119 - 122, 1980.

POUKKA, O.; ISOTALO, I.; GULLINCHSEN, J.

Optimal delignification degrees of cooking and oxygen/ alkali stage in production of ECF bleached softwood kraft. Paperi Ja Puu, v.81, n.4, p. 316-324, 1999.

RESTREPO, G., (Personal communication Forestry Engineer. Research, Cenpapel, Colombia, 2003).

RODRÍGUEZ, S.; TORRES, M. Obtención de pulpa Kraft de Pinus patula, Pinus taeda y Pinus elliottii. Ciencia e Investigación

Forestal, v.6, n.1, p. 47-60, 1992.

SALOMÃO, K.G. Características e branqueabilidade de polpas kraft/ polisssulfeto de Eucalyptus e de Pinus. 2001.112f. Dissertação (Mestrado em Ciências Florestais) - Universidade Federal de Viçosa, Viçosa, 2001.
SALVADOR, E. Efeito da deslignificação com oxigênio nas propriedades físicomecânicas de polpas kraft , 2000.115f. Dissertação (Mestrado em Ciências Florestais) Universidade Federal de Viçosa, Viçosa, 2000.

SHACKFORD, L. et al. Otimização da tecnologia de deslignificação com oxigênio, In: SEMINÁRIO DE DESLIGNIFICAÇÃO, 2., São Paulo, 1999. Seminário... São Paulo: 1999. p-46-61

SILVA, F.G. et al. Avaliação da qualidade da madeira de Pinus patula var. tecunumanii visando a produção de celulose kraft e pasta mecânica. O Papel, n. 6, p.32-35, 1994.

SOINIL, P. et al. Effect of transition metals on oxygen delignification and peroxide bleaching. Paperi Ja Puu - Paper and Timber, v.80, n.2, p. 116-121, 1998.

WRIGHT, J.A.; JAMEEL, H.; DVORAK, W. Laboratory kraft pulping of juvenile tropical pines: Pinus patula, P. tecunumanii, $P$. masciminoi, and P. chiapensis. Tappi Journal, v.79, n.1, p.91-96, 1995.

WRIGHT, J.A.; SABOURIN, M.J.; DVORAK, W.S. Laboratory results of TMP and CTMP trials with Pinus patula, P. tecunumanii, and P. caribaea var. hondurensis. Tappi Journal., v.78, n.1, p.91-96, 1995. 